\title{
Bacterioplankton growth in seawater: I. Growth kinetics and cellular characteristics in seawater cultures
}

\author{
J. W. Ammerman, J. A. Fuhrman*, Å. Hagström** and F. Azam \\ Institute of Marine Resources, A-018, Scripps Institution of Oceanography, University of California, San Diego, La Jolla, \\ California 92093, USA
}

\begin{abstract}
The major objective of this study was to examine the ability of marine bacteria to grow in paricle-free unenriched seawater and to characterize this growth. A natural assemblage of marine bacteria was inoculated into particle-free $(0.22 \mu \mathrm{m}$ filtered) seawater. The inoculum, mainly free-living bacteria, was prepared by filtering seawater through a $0.6 \mu \mathrm{m}$ Nuclepore filter. Growth on dissolved organic matter was unambiguously demonstrated by parallel increases in cell number, ATP, and biovolume. Doubling times of these 'seawater cultures' were 9 to $18 \mathrm{~h}$, comparable to those of similar bacterial assemblages in the natural environment. These similarities in growth kinetics imply that for at least some of the bacteria, the growth conditions were similar to those in the sea, and growth was not an artifact of containment. The average cell volume more than doubled during the log phase of growth and then returned to near initial levels. Preferential predation on such large cells is suggested as an explanation for their rare occurrence in the sea. Seawater cultures should be useful for studies of the nutrition, chemical composition, and other aspects of the physiological ecology of marine bacteria.
\end{abstract}

\section{INTRODUCTION}

There is only limited conclusive information in the literature on growth of bacteria in seawater. It has often been assumed that the dissolved organic matter (DOM) in seawater is too dilute to support significant bacterial growth, and that bacterial growth largely occurs on particles; free-living bacteria are thought to be dormant (Wangersky, 1977; Stevenson, 1978). However, other recent studies suggest that free-living bacteria are actively growing (Azam and Hodson, 1977; Fuhrman and Azam, 1982). Bacterial numbers have been shown to increase in seawater filtered through a $3 \mu \mathrm{m}$ Nuclepore filter (Sieburth et al., 1977; Larsson and Hagström, 1979; Fuhrman and Azam, 1980), but the presence of small particles and bacteriovores obscures the source of nutrition and actual bacterial growth rate. Some workers have shown an increase in cell numbers when isolates of marine bacteria were

- Present address: Marine Sciences Research Center, State University of New York at Stony Brook, Long Island, New York 11794, USA

- Permanent address: Department of Microbiology, University of Umeå, S-901 87 Umeå, Sweden inoculated into unenriched particle-free seawater (Jannasch, 1969; Carlucci and Shimp, 1974; Carlucci and Shimp, 1976; Williams and Carlucci, 1976; Carlucci and Williams, 1978). Recently, Ferguson et al. (1984) showed that natural bacterioplankton placed in containers increased both in cell number and cell volume. Novitsky and Morita (1977), however, found that cultured marine bacteria, when resuspended in seawater, may divide into smaller cells without net increase in biomass. Thus, whether bacteria realize net growth in particle-free seawater is still an unsettled issue.

We and others have previously argued (Bell and Mitchell, 1972; Azam and Hodson, 1981; Azam and Ammerman, 1984) that the presence of particulate sources of DOM (including phytoplankton) in seawater may create microzones of high DOM concentration. Bacterioplankton appear to be adapted to take up nutrients at higher rates from such microzones, yet have high-affinity uptake systems for effectively utilizing DOM from the bulk phase seawater (Azam and Hodson, 1981). As a first step towards elucidating bacterioplankton-organic matter interactions, we have studied bacterioplankton metabolism and growth in particle-free seawater. The results are reported here in a series of papers describing growth kinetics and cellu- 
lar characteristics, organic matter transformations during growth, and aspects of the biochemistry of growth of bacterioplankton in seawater. Studies were done in batch, semi-continuous, and continuous modes of supply of seawater nutrients to bacterioplankton. In this first paper, we examine bacterial growth, its kinetics, and describe some cellular characteristics during growth.

\section{MATERIALS AND METHODS}

Growth in particle-free seawater. Surface seawater ( 0 to $1 \mathrm{~m}$ ), for both the bacterial inoculum and growth medium, was collected year around (seawater temperature 14 to $20^{\circ} \mathrm{C}$ ) in sterile polycarbonate flasks from the end of the pier at Scripps Institution of Oceanography $\left(32^{\circ} 53^{\prime} \mathrm{N}, 117^{\circ} 15^{\prime} \mathrm{W}\right)$, unless otherwise specified. The growth medium was unsupplemented seawater which had been sterile-filtered through pre-washed $0.30 \mu \mathrm{m}(\mathrm{PH})$ or $0.22 \mu \mathrm{m}$ (GS) pore-size Millipore filters. In some cases, where specified, the water was also autoclaved following filtration. These 'seawater cultures' (total volume 0.1 to 1 1) were started by addition of 2 to $20 \%(\mathrm{v} / \mathrm{v})$ of 1.0 or $0.6 \mu \mathrm{m}$ Nuclepore filtrates (filtered by gravity or gentle vacuum) to the sterile seawater growth medium in acid-cleaned polycarbonate or Pyrex glass containers. About $70 \%$ of the bacteria in Scripps-pier seawater are $0.6 \mu \mathrm{m}$ in diameter or smaller (Fuhrman, 1981); virtually all pass a $1.0 \mu \mathrm{m}$ filter (Ammerman, unpubl.). Cultures were incubated in the dark at $18^{\circ} \mathrm{C}$ and were sampled by sterile techniques.

Determination of bacterial number, growth rate, ATP, and cell volume. The number of bacteria in seawater cultures was determined by acridine orange direct counts (AODC; Hobbie et al., 1977). Growth rate $(\mu)$ was calculated from the increase in cell number by an exponential fit of the linear portion of the growth curve (semilog plot). Samples for ATP determination were filtered onto $0.45 \mu \mathrm{m}$ (HA) Millipore filters and extracted in boiling Tris buffer. ATP was determined by the firefly luminescence assay (Holm-Hansen and Booth, 1966; Karl, 1980), and calculated for each sample by integrating the area under the light emission curve.

Individual cell volume was determined by measuring cell dimensions in enlargements of AODC micrographs (total magnification about $2000 \times$ ) and calculating volume with the appropriate equation (Fuhrman, 1981). Cells were operationally defined as rods if their length and width in the micrograph differed by more than $0.1 \mu \mathrm{m}$. If the difference in the 2 dimensions was $0.1 \mu \mathrm{m}$ or less, they were classed as cocci (spheres). The limit of resolution was about $0.05 \mu \mathrm{m}$.

\section{RESULTS}

\section{Kinetics of growth}

The growth curve of a seawater culture in Scrippspier seawater is shown in Fig. 1. This experiment is representative of many we have done, but here we

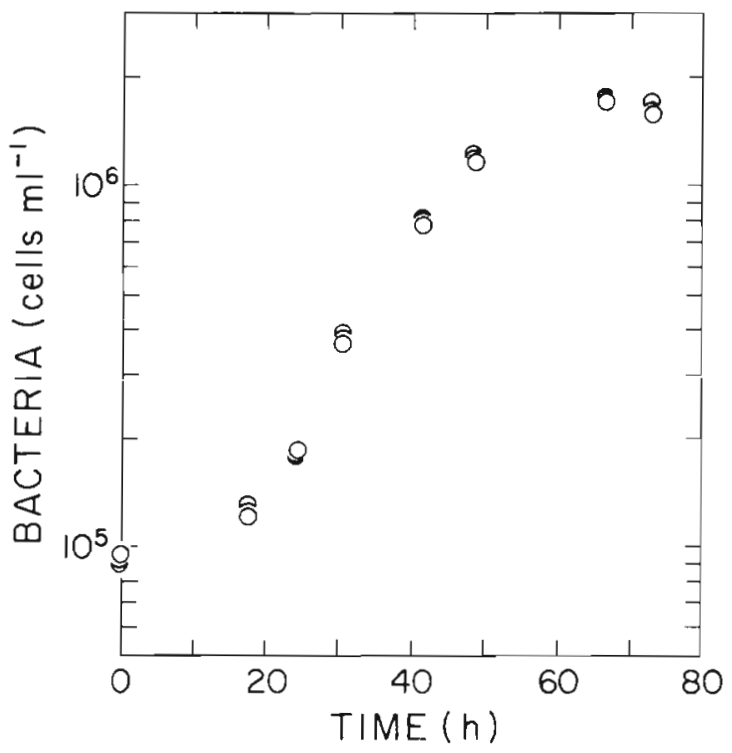

Fig. 1. Growth curve of a bacterial seawater culture. Cell counts from each of 2 replicate containers are shown at every time point

sampled more frequently. From an initial population of $9 \times 10^{4}$ cells $\mathrm{ml}^{-1}$, the population reached a plateau at $1.9 \times 10^{6}$ cells $\mathrm{ml}^{-1}$ in $63 \mathrm{~h}$. This curve resembles the growth curve of single species batch cultures in rich media with lag, exponential, and stationary phases (Stanier et al., 1976). The reproducibility between replicate culture flasks was good. The doubling time $(\ln 2 / \mu)$ during the log phase of growth was $9.3 \mathrm{~h}$. Offshore seawater collected from a depth of $100 \mathrm{~m}$ also supported the growth of bacteria. An inoculum from Scripps pier grew from $7.5 \times 10^{4}$ cells ml $^{-1}$ to $2.4 \times 10^{6} \mathrm{ml}^{-1}$ in less than $2 \mathrm{~d}$ in this $100 \mathrm{~m}$ seawater.

We performed a series of experiments to ascertain the minimum inoculum size required to grow a seawater culture and the maximum cell density achieved. Growth to cell densities greater than $10^{5} \mathrm{ml}^{-1}$ was detectable within $3 \mathrm{~d}$ in all 4 cultures where the inoculum was at least 130 cells $\mathrm{ml}^{-1}$ (40 ml cultures). Only 1 of 2 similar cultures with the initial cell densities of $13 \mathrm{ml}^{-1}$ reached $10^{5}$ cells ml-1 within 3 to $4 \mathrm{~d}$. Ten samples with an average initial concentration of 1 bacterium $\mathrm{ml}^{-1}(10 \mathrm{ml}$ cultures $)$ showed no measurable growth at any time during $35 \mathrm{~d}$ of incuba- 
tion. While seawater cultures generally level off at about $2 \times 10^{6}$ cells $\mathrm{ml}^{-1}$ (Fig. 1 and 3), we have occasionally obtained higher yields (Fig. 2). In one experiment with seawater from Scirpps pier (inoculum $8 \times 10^{4}$ cells $\mathrm{ml}^{-1}$ ), the cell density reached $1.2 \times 10^{7}$ $\mathrm{ml}^{-1}$ in less than $3 \mathrm{~d}$.

\section{Wall growth}

To determine if growth on the walls of the container contributed to the bacterial growth in particle-free seawater, we transferred a seawater culture to a new sterilized $125 \mathrm{ml}$ Erlenemeyer flask after each sampling ( 5 times). During nearly $70 \mathrm{~h}$ of incubation, there was little difference between the bacterial growth rate in this culture and two controls that were not transferred (Fig. 2). In fact growth in the transferred culture

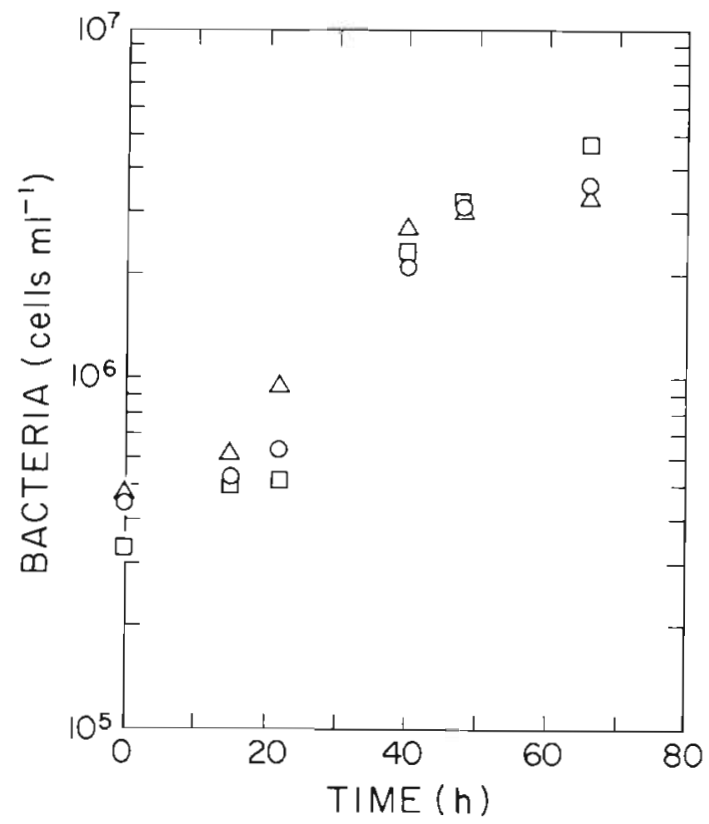

Fig. 2. Effect of wall growth and medium autoclaving on growth of bacterial seawater cultures. The 3 seawater cultures shown were grown on sterile-filtered seawater $(\Delta)$, filteredautoclaved seawater $(0)$, and filtered-autoclaved seawater with transfer to a sterile container after each sampling ( $\square$ )

was slightly faster (doubling time was $15.1 \mathrm{~h}$ vs. $18.2 \mathrm{~h}$ and $19.8 \mathrm{~h}$ for the other two). Average doubling time of all 3 treatments in Fig. 2 was $17.6 \mathrm{~h}$.

\section{Effects of autoclaving the medium}

The above experiment also showed that autoclaving the filtered seawater medium had no effect on the growth rate of seawater cultures. The growth rates of the 2 control cultures (Fig. 2), one grown in sterilefiltered seawater, the other in filtered-autoclaved seawater, were very similar. Autoclaving unfiltered or less finely filtered seawater, however, increased the yield of bacteria in a separate 60 h seawater culture. Using a seawater culture grown in GS (0.22 $\mu \mathrm{m}$ Millipore) filtered and autoclaved seawater as a $100 \%$ yield $\left(1.7 \times 10^{6}\right.$ cells $\left.\mathrm{ml}^{-1}\right)$, the yields from seawater cultures where the seawater had previously been filtered through the filter specified (before autoclaving) were as follows: $0.2 \mu \mathrm{m}$ Nuclepore, $143 \%$; $1.0 \mu \mathrm{m}$ Nuclepore, $133 \%$; $5.0 \mu \mathrm{m}$ Nuclepore, $135 \%$; unfiltered, $270 \%$.

\section{Biomass of seawater cultures}

The next question we addressed was whether or not the increase in cell number seen in seawater cultures (Fig. 1 and 2) represented also an increase in bacterial biomass, or whether cell division occurred without a net biomass increase producing smaller cells (Novitsky and Morita, 1976, 1977, 1978). We grew a seawater culture and simultaneously monitored the total cell number, biovolume, and ATP. All these parameters increased in parallel (Fig. 3), indicating that the biomass increased as well as the population size. All 3 rose exponentially for the first $72 \mathrm{~h}$ and then leveled off. ATP and biovolume dropped slightly by $122 \mathrm{~h}$ while the cell number continued to rise slowly.

\section{Cell volume}

The seawater culture showed morphological diversity over the entire $122 \mathrm{~h}$ culture period (Fig. 3), though this diversity was greatest at the beginning and the end. Table 1 shows the mean and standard error of the cell volume (determined from AODC micrographs) at 4 different stages of this seawater culture. Values are given for both rods and cocci as well as the combined totals. Since some of the data are not normally distributed (even when log transformed), we used nonparametric one-way analysis of variance (KruskalWallis $\mathrm{H}$ test) to test for differences in the mean volume within each class of cells (rods, cocci, and total) over the time course of the culture growth. This test showed that the means of both the rods and the totals were significantly different at the $1 \%$ level, and the cocci were significantly different at the $5 \%$ level but not the $1 \%$ level.

The change in mean cell volume with time is shown in Fig. 4 for each class of cells. The mean cell volume of the total assemblage increased 2.5 -fold at $49 \mathrm{~h}$ and 
Table 1. Summary of cell volume data $\left(\mu \mathrm{m}^{3}\right)$ for the seawater culture shown in Fig. 3

\begin{tabular}{|c|c|c|c|c|c|c|c|c|c|c|c|}
\hline \multirow[t]{2}{*}{ Hour } & \multicolumn{4}{|c|}{ Cocci } & \multicolumn{4}{|c|}{ Rods } & \multicolumn{3}{|c|}{ Total } \\
\hline & $\bar{x}^{a}$ & SE & $\mathrm{n}$ & $\%$ of $\mathrm{T}$ & $\bar{x}$ & SE & $\mathrm{n}$ & $\%$ of $\mathrm{T}$ & $\bar{x}$ & SE & $\mathrm{n}$ \\
\hline 0 & 0.086 & 0.005 & 52 & 43 & 0.107 & 0.008 & 68 & 57 & 0.098 & 0.005 & 120 \\
\hline 49 & 0.125 & 0.023 & 15 & 16 & 0.269 & 0.018 & 78 & 84 & 0.246 & 0.017 & 93 \\
\hline 72 & 0.107 & 0.009 & 30 & 27 & 0.185 & 0.010 & 83 & 73 & 0.165 & 0.008 & 113 \\
\hline 122 & 0.083 & 0.014 & 46 & 43 & 0.165 & 0.014 & 62 & 57 & 0.130 & 0.011 & 108 \\
\hline
\end{tabular}

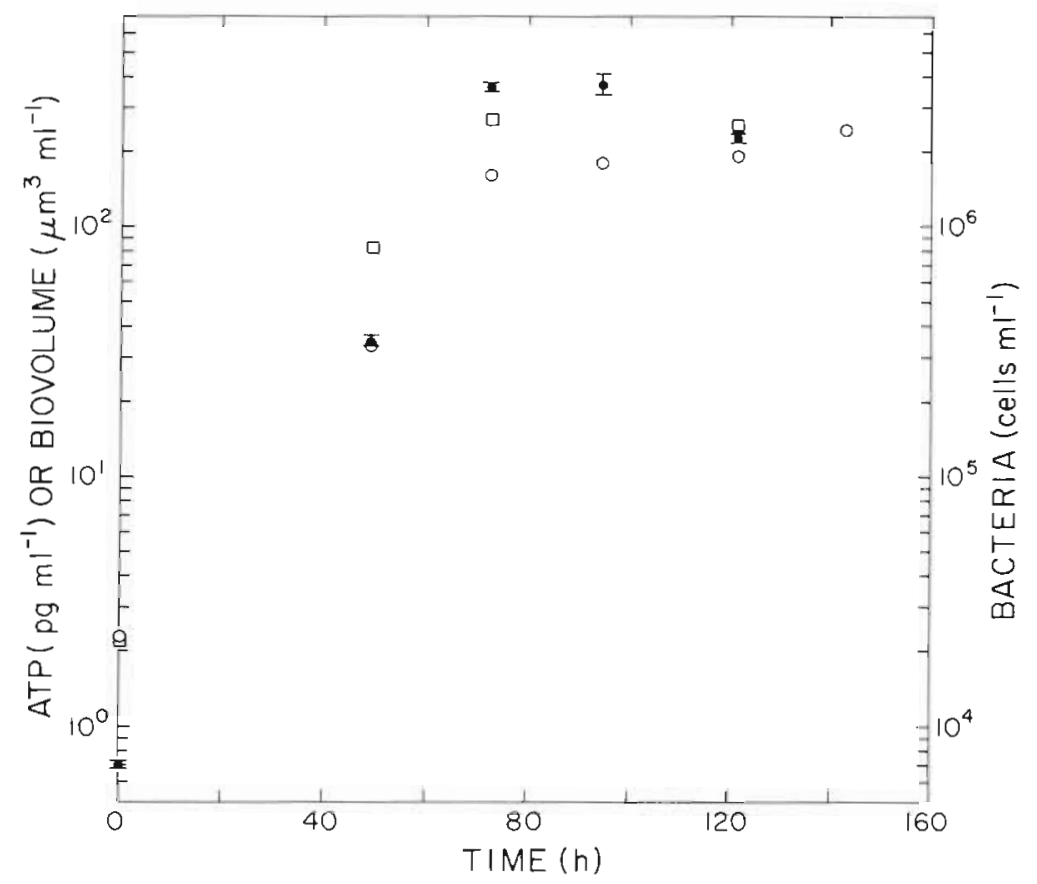

Fig. 3. Time course of bacterial cell number $(O)$ and biomass of a seawater culture. Biomass is represented by total $\operatorname{ATP}($ mean and range, $\mathrm{n}=2$ ) and total cell volume (biovolume, $\square$ )

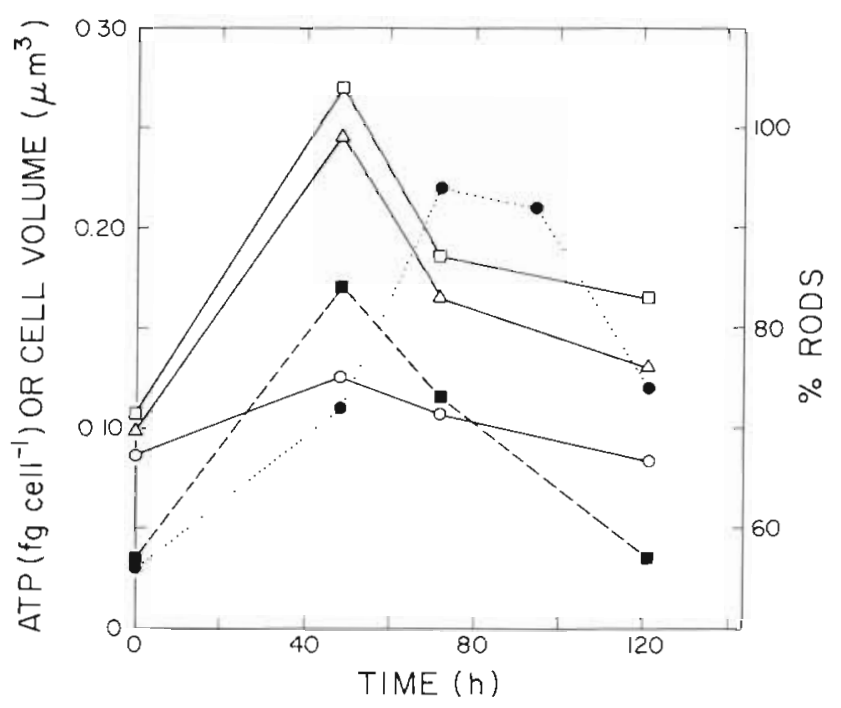

Fig. 4. Variation of ATP cell ${ }^{-1}(\bullet)$ and volume cell ${ }^{-1}$ with time for the seawater culture in Fig. 3. Volume cell ${ }^{-1}$ is shown for the following categories of cells: total $(\Delta)$, rods $(\square)$, and cocei (O). Percent of total celis classified as rods ( $\bullet$ is also shown then dropped again to only 1.3 times the original at $122 \mathrm{~h}$. This confirms our frequent qualitative observation of an increase in cell size during exponential growth of a seawater culture, followed by a decrease during the stationary phase.

Fig. 4 shows that most of the increase in cell volume occurred in the rod-shaped fraction, which also increased from 57 to $84 \%$ of the total cell number after $49 \mathrm{~h}$ of incubation. After $122 \mathrm{~h}$, the mean cell volume of the rod fraction was still $150 \%$ of the original, but the number of rods as a percent of the total bacteria had returned to their original value. The cocci increased about $45 \%$ in mean volume at $49 \mathrm{~h}$, but had returned to their original volume after $122 \mathrm{~h}$ of incubation.

Volume-frequency distributions at 4 different times during growth of the above seawater culture (from Fig. 3) are shown in Fig. 5. Volume distributions of rods, cocci, and the total were nearly identical for the culture inoculum $(0 \mathrm{~h})$. As growth proceeded, all distributions shifted to higher values, especially the rods. (The distributions of total and rods were similar during 
Fig. 5. Volume-frequency distributions at 4 different times for the seawater bacterial culture in Fig. 3. Distributions are shown for the following categories of cells: total $(\Delta)$, rods $(\square)$, and cocci $(O)$

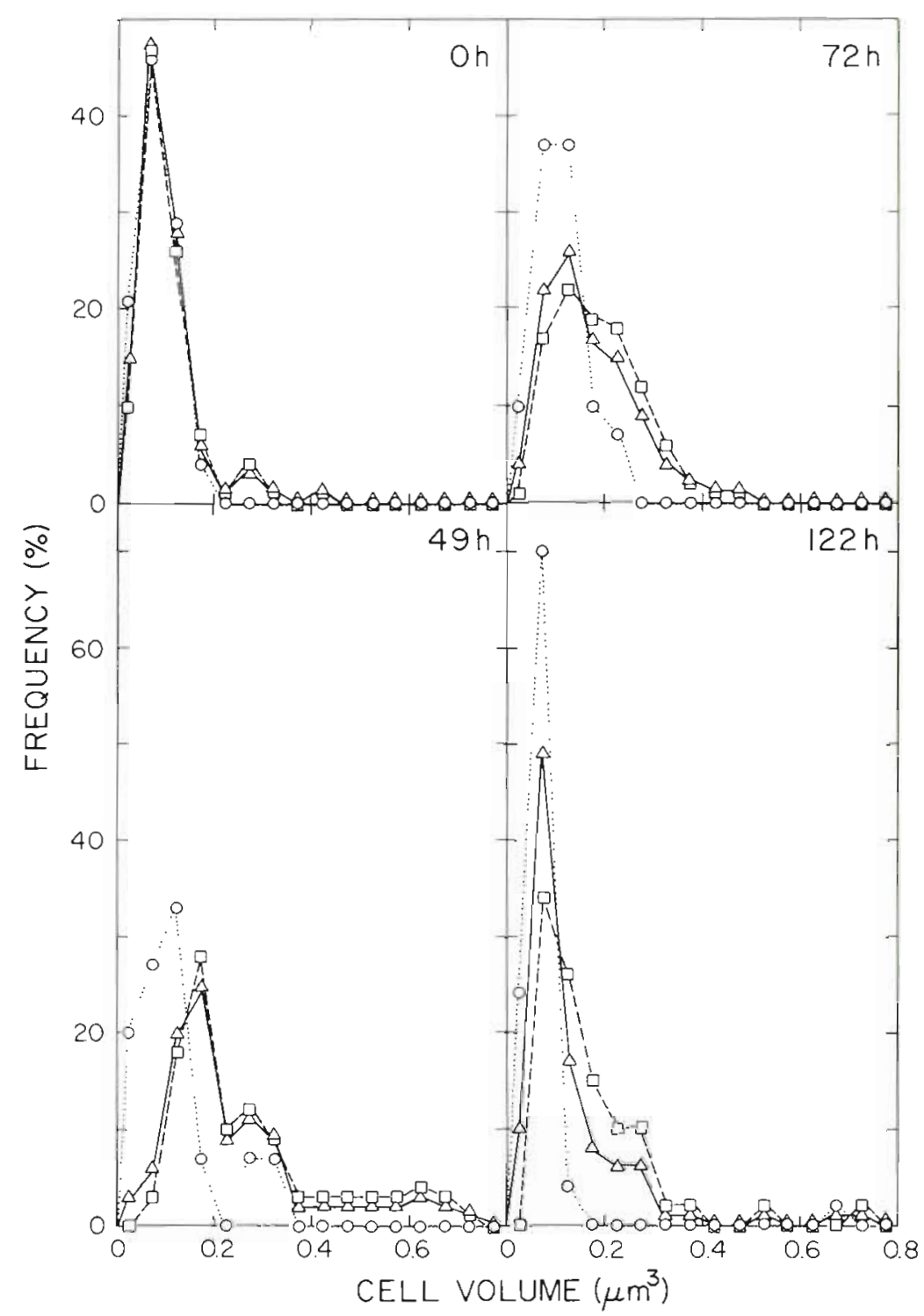

growth in particle-free seawater at the expense of DOM. Population-average doubling times were 9 to $18 \mathrm{~h}$, comparable to the doubling time for natural assemblages (Hagström et al., 1979; Fuhrman and Azam, 1980, 1982). The increase in cell number was paralleled by an increase in bacterial biomass (discussed below). This basic experiment could be repeated without fail. The lag phase shown in Fig. 1 was not always present; we did not investigate the cause of this lag but it suggests that in some experiments not all the bacteria were growing. The cell yield was generally about $2 \times 10^{6}$ bacteria $\mathrm{ml}^{-1}$, about twice the cell density in surface seawater. The production of $2 \times 10^{6}$ bacteria represented the consumption of less than $10 \%$ of the dissolved organic carbon (DOC) in seawater (20 fg Cell ${ }^{-1}, 50 \%$ assimilation efficiency; $1.5 \mu \mathrm{g}$ DOC $\mathrm{ml}^{-1}$ seawater, or $5.3 \%$ DOC utilized). These observations support past assertions that only a small
Our results clearly show that at least part of the bacterioplankton assemblage is capable of rapid

\section{DISCUSSION}


fraction of DOM is utilizable (Bada and Lee, 1977) and suggest that the growth of free-living bacteria is tightly coupled to new inputs of utilizable nutrients. In surface seawater containing $1 \times 10^{6}$ bacteria ml $^{-1}$ there appears to be just enough nutrients to support 1 to 2 doublings of the assemblage.

The interpretation of these laboratory observations in terms of the growth of free-living bacterioplankton in the sea must take into account certain possible artifacts. These pertain to both properties of the growth milieu (inadvertent nutrient additions by cell breakage during filtration or autoclaving; cryptic growth; wall growth; presence of growth inhibitors such as heavy metals) and properties of the cells (increase in cell number but diminution of cell size, species selection).

Did filtration and handling of seawater add significantly to the DOM? Measurement of dissolved free amino acids (DFAA) in seawater culture media should be a good indicator of addition of DOM due to cell breakage. DFAA analysis by HPLC showed that the levels in the unsupplemented seawater medium were not significantly increased by our handling or filtration procedures (T. R. Jacobsen, pers. comm.). Leakage of all the phytoplankton and bacteria cell pools contained in a volume of seawater would be unlikely to more than double the DFAA concentrations anyway, since pool concentrations are $\mathrm{mM}$ (Cohen and Monod, 1957; Herbert et al., 1971; Dortch, 1982) and the cells occupy only $10^{-6}$ of the total volume (Azam and Ammerman, 1984). Significant addition of airborne organic nutrients (Geller, 1983) is unlikely since our culture flasks were tightly closed and not shaken.

Sterile-filtration of media is satisfactory for most small-volume seawater cultures, though autoclaving may be necessary for larger ones (Hagström et al., 1984). Jannasch (1969) reported that autoclaving enhanced the growth of 3 isolates grown in chemostats of unsupplemented seawater. This was probably because the seawater was not filtered before autoclaving. We found that autoclaving unfiltered seawater nearly tripled the yield of a seawater culture grown in it. In contrast, autoclaving pre-filtered $(0.22 \mu \mathrm{m}$ Millipore) seawater did not affect the growth rate of seawater cultures (Fig. 2) and only slightly increased the levels of DFAA (T. R. Jacobsen, pers. comm.) and total amino acids (Hagström et al., 1984).

A consideration which has tended to inhibit experimentation on natural populations of marine bacteria is 'wall-growth' (ZoBell and Anderson, 1936). We reasoned that if a seawater culture was frequently transferred to a fresh container, significant populations of bacteria would not develop on the container walls. A seawater culture thus treated could then be compared with one grown in a single flask to determine the extent of growth enhancement. After 60 h, 'transferred' and 'non-transferred' seawater cultures had the same growth rate and cell-yield (Fig. 2) suggesting that for unenriched seawater incubations wall-growth may not be a serious problem. In another study (Hagström et al., 1984) a seawater culture was run in a continuous culture mode, and the bacterial growth rate on submerged glass coverslips was monitored. Bacteria on coverslips grew at the same rate as those in the liquid phase, and only a trivial fraction of the bacterial population was calculated to be present on the container walls.

The increase in total bacterial biovolume and ATP (Fig. 3) shows that seawater cultures generated new biomass from unsupplemented seawater. Ferguson et al. (1984) also found an increase in the total bacterial biovolume of natural bacterioplankton confined for $34 \mathrm{~h}$. In contrast, when a marine isolate grown in rich medium was harvested and resuspended in unsupplemented natural or artificial seawater (Novitsky and Morita, 1976, 1977, 1978), the cell number increased greatly (6 to 400 times) in the first week and then declined. Cell volume, however, decreased about 10fold within the first week and another 10-fold over the next $5 \mathrm{wk}$. Therefore, the total bacterial biomass in these studies decreased with time, and the increase in cell number was an apparent response to starvation rather than an increase in biomass.

Cellular ATP could also be used as a check on cell death and cryptic growth (Postgate, 1976). The ATP: carbon ratio in our seawater culture increased during growth, with a peak at $72 \mathrm{~h}$. High ATP:C was maintained during the stationary phase. ATP:C ratios at all sampling times were within the range reported for exponentially growing cultures of many isolates (summarized by Karl, 1980). It is unlikely, therefore, that a significant accumulation of dead bacteria occurred.

Morphological diversity of the bacteria observed throughout the growth and stationary phase of the seawater culture (Fig. 3) suggests that many different bacterial strains were present, the culture was not taken over by just 1 or 2 . A separate seawater culture, which was examined periodically over a $26 \mathrm{~d}$ period, displayed a similar diversity. In both cases the diversity decreased during exponential growth and then increased again during stationary phase (see discussion on shape changes below). A seawater continuous culture (Hagström et al., 1984) also maintained morphological diversity for its entire $24 \mathrm{~d}$ culture period.

Our results show that the average cell volume increased during exponential growth and then returned to near-initial levels during stationary phase (Table 1, Fig. 4). Furthermore, most of this increase in volume took place in the rod-shaped fraction of the cells, which also increased as a percent of the total cell number during exponential growth and then returned to their initial percentage. Previous work with cultures 
of enteric bacteria (Schaechter et al., 1958; Donachie 1968) has shown a logarithmic increase in cell mass with increasing growth rate. Escherichia coli also increases its length (Donachie et al., 1976) and slightly decreases its diameter or width (Trueba and Woldringh, 1980) at higher growth rates.

Coccoid bacteria probably became rod-shaped during exponential growth and then returned to a coccoid shape. The alternative explanation, that only rodshaped bacteria grew, is unlikely since the coccoid forms would continualiy decline as a percentage of the total bacteria. Rod-to-sphere (and vice versa) conversions are well known in bacterial cultures (Henning et al., 1972; Fontana et al., 1979, and references therein), and can result from nutritional factors as well as other causes. Novitsky and Marita (1976) found that 4-wk starvation of a marine isolate in artificial seawater (after initial growth in a nutrient medium) caused the cells to shrink and change from a rod to a coccoid shape. Within $48 \mathrm{~h}$ after resuspension in a fresh nutrient medium, however, the cells had regained their original size and rod shape. Baker and Park (1975) also found that a Vibrio strain shrank in size and changed shape from a rod to a sphere after growth had stopped because of nutrient depletion. Similar transitions may have occurred in the seawater cultures.

If the above argument is valid, why is the sea not dominantly populated by large rod-shaped bacteria, instead of an assortment of small rods and cocci? Either the largest cells are quickly removed from seawater, or the growth of seawater cultures is somehow artificially stimulated and does not represent conditions in the sea (discussed above). Recent microautoradiographic studies (Tabor and Neihof, 1982; Fuhrman and Azam, 1982) suggest it is unlikely that the bacteria are small because they are dormant.

Cell size and morphological diversity of marine bacterial assemblages may be maintained by predators which preferentially remove the large, fast-growing bacteria. Many aquatic bacteriovores (including heterotrophic flagellates, ciliates, cladocerans, and salps) can feed more efficiently on particles $>2 \mu \mathrm{m}$ compared to smaller ones (Peterson et al., 1978; Harbison and McAlister, 1979; Fenchel, 1980, 1982a,b). However, most bacteria in seawater are smaller than $2 \mu \mathrm{m}$. Nonetheless, it was recently shown that at least one bacteriovore, the mussel Geukensia demissa, can effectively filter bacteria down to $0.5 \mu \mathrm{m}$ in size (Wright et al., 1982). If marine bacteriovores can preferentially exploit the larger bacteria, then the flux of bacterial biomass to higher trophic levels may be greater than currently estimated. The fact that seawater cultures lack these predators may explain why the bacteria in exponentially growing seawater cultures were larger than those found in seawater.
In contrast to the cell size, the maximum bacterial number in most seawater cultures (about $2 \times 10^{6}$ cells $\mathrm{ml}^{-1}$ ) was similar to natural bacterial populations in the surface waters of the Southern California Bight (Fuhrman et al., 1980) or slightly higher. The most likely explanation for the leveling off of seawater cultures at this cell density is that growth stopped due to the depletion of readily utilizable nutrients (organic or inorganic). Micro-predators or parasites, such as bacteriophages and bdellovibrios, probably occurred in seawater cultures but their impact on the population size was not studied.

Our results suggest that predation may control the size distribution of the bacteria. In the euphotic zone, however, where nutrients are continuously recycled, it seems unlikely that the bacterial population density (though maybe the growth rate) would be nutrientlimited as it was in seawater cultures. Therefore, predation may also control the population density, and could be a major determinant of bacterial biomass in the sea.

Seawater cultures are a useful experimental system in the study of marine microbial ecology and the biochemistry of bacterial growth in the sea. They have already been used in transport studies (Ammerman and Azam, 1982) and have been proposed for use in pollution studies (Azam et al., in press). They offer an important advantage over the natural seawater assemblages, in that detritus ( $>0.22 \mu \mathrm{m}$, except any formed after filtration) as well as non-bacteria organisms have been essentially excluded. This is useful for studying the chemical composition of bacteria and the biochemistry of bacterial growth. Seawater cultures are useful for physiological studies since the growth conditions are probably closer to those of free-living bacteria in seawater. Where differences are found between seawater cultures and natural bacterial assemblages, the basis of such differences may itself provide insights into the physiology of the natural bacterial assemblages. Semicontinuous and continuous seawater cultures have recently been used for nutritional studies (following paper). It may be possible to obtain pure cultures by serial dilutions of seawater cultures in particle-free seawater.

Acknowledgements. We thank E. Traganza for ATP analyses, E. Stewart and K. Robertson for programming assistance, T. R. Jacobsen, I. Koike, K. H. Nealson and B. B. Ward for stimulating discussions and comments on the manuscript, and $M$. A. Ogle for help in manuscript preparation. This work was supported by US Department of Energy contract DE-AT03-82ER60031 and National Science Foundation grant OCE7926458 


\section{LITERATURE CITED}

Ammerman, J. W., Azam, F. (1982). Uptake of cyclic AMP by natural populations of marine bacteria. Appl environ. Microbiol. 43: 869-876

Azam, F., Ammerman, J. W. (1984). Cycling of organic matter by bacterioplankton in pelagic marine ecosystems: microenvironmental considerations. In: Fasham, M. J. (ed.) Flows of energy and materials in marine ecosystems Plenum Press, New York, p. 345-360

Azam, F., Ammerman, J. W., Fuhrman, J. A., Hagström, A. (1984). Role of bacteria in polluted marine ecosystems. In: White, $H$. (ed.) Proceedings of the workshop on meaningful measures of marine pollution effects. NOAA, April 1982 , in press

Azam, F., Hodson, R. E. (1977). Size distribution and activity of marine microheterotrophs. Limnol. Oceanogr. 22: 492-501

Azam, F., Hodson, R. E. (1981). Multiphasic kinetics for Dglucose uptake by assemblages of natural marine bacteria. Mar. Ecol. Prog. Ser. 6: 213-222

Bada, J. L., Iee, C. (1977). Decomposition and alteration of organic compounds dissolved in seawater. Mar. Chem. 5: $523-534$

Baker, D. A., Park, R. W. A. (1975). Changes in morphology and cell wall structure that occur during growth of Vibrio sp. NCTC4716 in batch culture. J. gen. Microbiol. 86: $12-28$

Bell, W. H., Mitchell, R. (1972). Chemotactic and growth responses of marine bacteria to algal extracellular products. Biol. Bull. mar. biol. Lab., Woods Hole 143: 265-277

Carlucci, A. F., Shimp, S. L. (1974). Isolation and growth of a marine bacterium in low concentrations of substrate. In: Colwell, R. R., Morita, R. Y. (ed.) Effect of the ocean environment on microbial activities. University Park Press, Baltimore, p. 363-367

Carlucci, A. F., Shimp, S. L. (1976). Distribution, isolation, and cultural characteristics of low-nutrient marine bacteria. University of California, Institute of Marine Resources, Research on the Marine Food Chain, Progress Report, July 1975-June 1976, IMR ref. 76-7, p. 827-875

Carlucci, A. F., Williams, P. M. (1978). Simulated in situ growth rates of pelagic marine bacteria. Naturwissenschaften 65: 541-542

Cohen, G. N., Monod, J. (1957). Bacterial permeases. Bacteriol. Rev. 21: 169-194

Donachie, W. D. (1968). Relationship between cell size and time of initiation of DNA replication. Nature, Lond. 219: $1077-1079$

Donachie, W. D., Begg, K. J., Vicent, M. (1976). Cell length, cell growth and cell division. Nature, Lond. 264: 328-333

Dortch, Q. (1982). Effect of growth conditions on accumulation of internal nitrate, ammonium, amino acids, and protein in three marine diatoms. J. exp. mar. Biol. Ecol. 61: 243-264

Fenchel, T (1980). Suspension feeding in ciliated protozoa: feeding rates and their ecological significance. Microb. Ecol. 6: 13-25

Fenchel, T. (1982a). Ecology of heterotrophic microflagellates. I. Some important forms and their functional morphology Mar. Ecol. Prog. Ser. 8: 211-223

Fenchel, T. (1982b). Ecology of heterotrophic microflagellates. IV. Quantitative occurrence and importance as bacterial consumers. Mar. Ecol. Prog. Ser 9: 35-42

Ferguson, R. L., Buckley, E. N., Palumbo, A. V (1984). Response of marine bacterioplankton to differential filtration and confinement. Appl. environ. Microbiol. 47: 49-55
Fontana, R., Canepari, P., Satta, G. (1979). Alterations in peptidoglycan chemical composition associated with rodto-sphere transition in a conditional mutant of Klebsiella pneumoniae. J. Bacteriol. 139: 1028-1038

Fuhrman, J. A. (1981). Influence of method on the apparent size distribution of bacterioplankton cells: epifluorescence microscopy compared to scanning electron microscopy. Mar. Ecol. Prog. Ser. 5: 103-106

Fuhrman, J. A., Ammerman, J. W., Azam, F. (1980). Bacterioplankton in the coastal euphotic zone: distribution, activity, and possible relationships with phytoplankton. Mar. Biol. 60: 201-207

Fuhrman, J. A., Azam, F. (1980). Bacterioplankton secondary production estimates for coastal waters of British Columbia, Antarctica, and California. Appl. environ. Microbiol. 39: 1085-1095

Fuhrman, J. A., Azam, F. (1982). Thymidine incorporation as a measure of heterotrophic bacterioplankton production in marine surface waters: evaluation and field results. Mar Biol. 66: $109-120$

Geller, A. (1983). Growth of bacteria in inorganic medium at different levels of airborne organic substrates. Appl. environ. Microbiol. 46: 1258-1262

Hagström, \&., Ammerman, J. W., Henrichs, S., Azam, F. (1984). Bacterioplankton growth in seawater: II. Organic matter utilization during steady-state growth in seawater cultures. Mar. Ecol. Prog. Ser. 18: 41-48

Hagström, Å., Larsson, U., Horstedt, P., Normark, S. (1979). Frequency of dividing cells, a new approach to the determination of bacterial growth rates in aquatic environments. Appl. environ. Microbiol. 37: 805-812

Harbison, G. R., McAlister, V. L. (1979). The filter-feeding rates and particle retention efficiencies of three species of Cyclosalpa (Tunicata, Thalaiacea). Limnol. Oceanogr. 24 875-892

Henning, U., Rehn, K., Braun, V., Hohn, B. (1972). Cell envelope and shape of Escherichia coli K12. Properties of a temperature-sensitive rod mutant. Eur. J. Biochem. 26 $570-586$

Herbert, D., Phipps, P. J., Strange, R. E. (1971). Chemical analysis of microbial cells. In: Norris, J. R., Ribbons, D. W. (ed.) Methods in microbiology, Vol. 5B. Academic Press, London, p. 209-344

Hobbie, J. E., Daley, R. J., Jasper, S. (1977). Use of Nuclepore filters for counting bacteria by fluorescence microscopy. Appl. environ. Microbiol. 33: 1225-1228

Holm-Hansen, O., Booth, C. R. (1966). The measurement of adenosine triphosphate in the ocean and its ecological significance. Limnol. Oceanogr. 11: 510-519

Jannasch, H. W. (1969). Estimations of bacterial growth rates in natural waters. J. Bacteriol. 99: 156-160

Karl, D. M. (1980). Cellular nucleotide measurements and applications in microbial ecology. Microbiol. Rev. 44; 739-796

Larsson, U., Hagström, Å. (1979). Phytoplankton exudate release as an energy source for the growth of pelagic bacteria. Mar. Biol. 52: 199-206

Mopper, K., Lindroth, P. (1982). Diel and depth variations in dissolved free amino acids and ammonium in the Baltic Sea determined by shipboard HPLC analysis. Limnol. Oceanogr. 27: 336-347

Novitsky, J. A., Morita, R. Y. (1976). Morphological characterization of small cells resulting from nutrient starvation of a physchrophilic marine vibrio. Appl. environ. Microbiol. 32: $617-622$ 
Novitsky, J. A., Morita, R. Y. (1977). Survival of a physchrophilic marine vibrio under long-term nutrient starvation. Appl. environ. Microbiol. 33: 635-641

Novitsky, J. A., Morita, R. Y. (1978). Possible strategy for the survival of marine bacteria under starvation conditions. Mar Biol. 48: 289-295

Peterson, B. J., Hobbie, J. E., Haney, J. F. (1978). Daphnia grazing on natural bacteria. Limnol. Oceanogr. 23: 1039-1044

Postgate, J. R. (1976). Death in macrobes and microbes. In: Gray, T. R. G., Postgate, J. R. (ed.) The survival of vegetative microbes. 26th Symposium of the Society for General Microbiology. Cambridge University Press, Cambridge, p. $1-18$

Schaechter, M., Maaloe, O., Kjeldgaard, N. O. (1958). Dependency on medium and temperature of cell size and chemical composition during balanced growth of Salmonella typhimurium. J. gen. Microbiol. 199: 592-606

Sieburgh, J. McN., Johnson, K. M., Burney, C. M., Lavoie, D. M. (1977). Estimation of in situ rates of heterotrophy using diurnal changes in organic matter and growth rates of picoplankton in diffusion culture. Helgoländer wiss. Meeresunters. 30: 565-574

Stanier, R. Y., Adelberg, E. A., Ingraham, J. (1976). The microbial world, 4th ed. Prentice-Hall, Inc., Englewood Cliffs, New Jersey
Stevenson, L. H. (1978). A case for bacterial dormancy in aquatic systems. Microb. Ecol. 14: 127-133

Tabor, P. S., Neihof, R. A. (1982). Improved microautoradiographic method to determine individual microorganisms active in substrate uptake in natural waters. Appl environ. Microbiol. 44: 945-953

Trueba, F. J., Woldringh, C. L. (1980). Changes in cell diameter during the division cycle of Escherichia coli. J. Bacteriol. 142: 869-878

Wangersky, P. J. (1977). The role of particulate matter in the productivity of surface waters. Helgolander wiss. Meeresunters. 30: 546-564

Williams, P. M., Carlucci, A. F. (1976). Bacterial utilization of organic matter in the deep sea. Nature, Lond. 262: 810-811

Wright, R. T., Coffin, R. B., Ersing, C. P., Pearson, D. (1982). Field and laboratory measurements of bivalve filtration of natural marine bacterioplankton. Limnol. Oceanogr. 27: 91-98

ZoBell, C. E., Anderson, D. Q. (1936). Observations on the multiplication of bacteria in different volumes of stored seawater and the influence of oxygen tension and solid surfaces. Biol. Bull. mar. biol. Lab. 71: 324-342 